\title{
Diversifikasi pengolahan pepaya di Kabupaten Enrekang
}

\author{
Hartati $^{1}$, Halifah Pagarra ${ }^{2}$, A. Mu'nisa ${ }^{3}$ \\ 1,2,3Fakultas Matematika dan Ilmu Pengetahuan Alam, Universitas Negeri Makassar
}

\begin{abstract}
Community service about papaya processing diversification has been carried out in Enrekang Regency. This activity was carried out to improve the knowledge and skills of the people in Enrekang district in processing papaya into products of economic value, namely jams papaya and shredded papaya. This activity is carried out in stages, namely the presentation of material, papaya fruit processing practices into jam and shredded, reflection and evaluation of activities. The results show that the community is able to process papaya into papaya jam products and shredded papaya, and produce products that have been packaged with labeling. This activity also received a very good response to the community. The results of this activity are expected to be developed into a home-based business to increase the income of housewives in Enrekang district.
\end{abstract}

Keywords: diversification, papaya, shredded papaya, papaya jam

\section{PENDAhuluan}

Kabupaten Enrekang terletak sebelah utara Makassar. Secara administratif terdiri dari sepuluh Kecamatan, 12 Kelurahan dan 96 Desa, dengan luas wilayah sebesar $1.786,01 \mathrm{Km}^{2}$. Terletak pada koordinat antara $3^{\circ} 14^{\prime} 36^{\prime \prime}$ sampai $03^{\circ} 50^{\prime} 00^{\prime \prime}$ Lintang Selatan dan $119^{\circ} 40^{\prime}$ '53" sampai $120^{\circ} 06^{\prime}$ 33" Bujur Timur. Batas wilayah kabupaten ini adalah sebelah utara berbatasan dengan Kabupaten Tana Toraja, sebelah timur dengan Kabupaten Luwu dan Sidrap, sebelah selatan dengan Kabupaten Sidrap dan sebelah barat dengan Kabupaten Pinrang. Kabupaten ini pada umumnya mempunyai wilayah Topografi yang bervariasi berupa perbukitan, pegunungan, lembah dan sungai dengan ketinggian $47-3.293 \mathrm{~m}$ dari permukaan laut serta tidak mempunyai wilayah pantai. Secara umum keadaan Topografi Wilayah wilayah didominasi oleh bukit-bukit/gununggunung yaitu sekitar $84,96 \%$ dari luas wilayah Kabupaten Enrekang sedangkan yang datar hanya $15,04 \%$. Penduduknya sebagian besar dengan mata pencaharian utama pada Sektor Pertanian $( \pm 65 \%)$.

Pepaya adalah tumbuhan yang berasal dari Meksiko Selatan dan Amerika Selatan, kini menyebar luas dan banyak ditanam di seluruh daerah tropis. Carica papaya L. adalah satusatunya jenis dalam genus papaya. Tanaman pepaya banyak ditemukan di Kabupaten Enrekang.
Secara tradisional biji pepaya dapat dimanfaatkan sebagai obat cacing gelang, gangguan pencernaan, diare, penyakit kulit, kontrasepsi pria, bahan baku obat masuk angin dan sebagai sumber untuk mendapatkan minyak dengan kandungan asamasam lemak tertentu (Warisno, 2003). Buah pepaya mengandung serat, vitamin $\mathrm{A}$, vitamin $\mathrm{B}$ kompleks, vitamin C, $\beta$-karoten, pektin, dgalaktosa, I-arabinosa, papain, papayotimin, dan vitokinase (Sulihandar \& Hartanti, 2013). Daun pepaya mengandung enzim papain, alkaloid karpaina, pseudokarpain, glikosid, karposid dan saponin. Penelitian yang telah dilakukan Peter et al. (2014) menggunakan ekstrak air dan metanol biji buah pepaya dan ekstrak air dan kloroform daun pepaya varietas Pusa dwarf Linn terhadap Salmonella typhi, Pseudomonas aeruginosa, Escherichia coli dan Staphylococcus aureus. Hasilnya membukti-kan efektifitas antibakteri ekstrak air dan metanol biji buah pepaya efektif menghambat pertumbuhan bakteri pathogen.

Berdasarkan hasil penelitian sebelumnya yang memberi informasi manfaat buah pepaya bagi kesehatan manusia dan banyaknya buah pepaya di kabupaten Enrekang yang hanya dimakan buah muda dan buah masak tanpa pengolahan. Oleh karena itu maka perlu dilakukan diversifikasi pengolahan pepaya kemasyarakat sebagai potensi lokal di Kabupaten Enrekang dengan menambah 
nilai ekonomi melalui pengolahan pepaya mejnadi berbagai produk yang bernilai ekonomi dan tahan lama, melalui kegiatan Program Kemitraan Masyarakat di kabupaten Enrekang. Produk ini memiliki prospek untuk dikembangkan menjadi usaha rumahan (Home Industry) yang dapat meningkatkan pendapatan rumah tangga.

\section{METODE PELAKSANAAN}

Tempat dan waktu pelaksanaan dilaksanakan di SMA Negeri 2 Enrekang Kabupaten Enrekang, Provinsi Sulawesi Selatan Tanggal 19 - 21 Juli 2019. Kegiatan ini dirancang dengan menggunakan metode penyuluhan dan praktik meliputi:

\section{A. Persiapan}

Dalam tahap persiapan ini ada beberapa hal yang dilakukan oleh tim pelaksana, yakni Koordinasi tim pelaksana untuk merencanakan pelaksanaan secara konseptual, operasional serta pembagian tugas masing-masing anggota tim, penentuan dan rekruitmen peserta kegiatan, seperti lembar presensi, pelatihan dan persiapan konsumsi, publikasi, izin penggunaan lokasi kegiatan, dan dokumentasi.

\section{B. Pelaksanaan Kegiatan}

Tahap pelaksanaan kegiatan ini diberikan kepada ibu-ibu dan remaja putri di kabupaten Enrekang, pelaksanaa kegiatan ini ada beberapa tahapan yaitu:

\section{Penyajian materi}

Materi pelatihan disajikan yaitu cara melakukan pengolahan buah pepaya menjadi selai pepaya dan proses pengolahan buah pepaya menjadi abon pepaya. Pemberian materi ini dilakukan oleh tim PKM.

2. Praktik pengolahan buah pepaya

Metode ini dilakukan dengan cara yaitu dipilih buah pepaya yang setengah matang warna agak kekuningan dan baik, lalu dikupas kulit luarnya kemudian dicuci sampai bersih. Selanjutnya buah pepaya yang telah bersih dipotong-potong lalu dicuci kembali. Buah pepaya yang telah bersih tersebut diolah menjadi selai dan diolah menjadi abon pepaya.

3. Praktik pembuatan selai pepaya dan abon pepaya

Para peserta dibagi dalam kelompok yang membuat selai pepaya dan yang membuat abon pepaya. Bahan dan proses pembuatannya seperti pada lampiran dalam proposal ini.

\section{Refleksi kegiatan PKM}

Diakhir kegiatan peserta dan tim PKM melakukan refleksi hasil kegiatan dan para peserta juga memberi evaluasi akan kegiatan ini.

\section{Evaluasi kegiatan}

Evaluasi kegiatan PKM dilakukan dengan cara yakni evaluasi terhadap proses dan evaluasi terhadap hasil. evaluasi terhadap proses dilihat dari keseriusan dan ketekunan para peserta dalam kegiatan praktek. Dan evaluasi terhadap hasil produk selai dan abon yang dihasilkan peserta dengan cara setiap peserta diberi angket untuk mengisi uji organoleptik terhadap rasa, aroma dan tekstur produk yang dihasilkan. Hasil angket yang dibagikan dan telah diisi dikumpulkan oleh tim PKM untuk selanjutnya dianalisis hasilnya untuk mendapatkan data.

\section{HASIL DAN PEMBAHASAN}

Hasil wawancara masyarakat di kabupaten Enrekang bahwa produksi pepaya kadang melimpah dan hanya dijual dalam bentuk buah segar. Sehingga untuk meningkatkan nilai ekonomi perlu dilakukan diversifikasi pengolahan pepaya untuk menghasilkan produk selai pepaya dan abon pepaya. Hasil kegiatan menunjukkan bahwa masyarakat memperoleh pengetahuan dan keterampilan dalam mengolah pepaya menjadi produk. Selama ini ibu-ibu rumah tangga belum mengetahui mengolah pepaya menjadi produk selai pepaya dan abon pepaya. Dengan kegiatan ini antusias ibu-ibu untuk mengikuti kegiatan ini sangat baik. Kegiatan dan produk yang dilakukan pada kegiatan ini dapat dilihat pada Gambar 1, 2, 3 , dan 4 . 


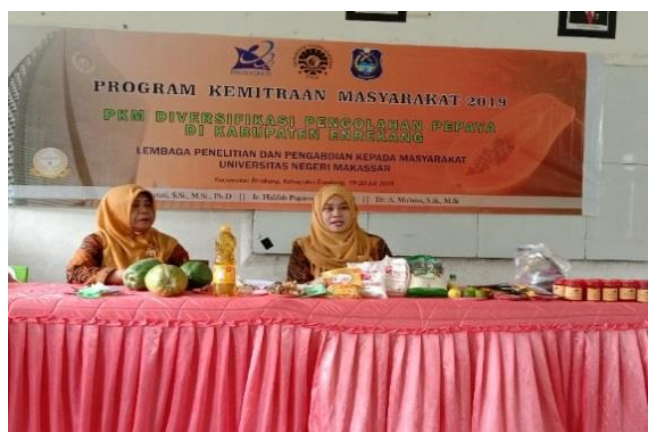

Gambar 1. Pemateri PKM mejelaskan materi pelatihan

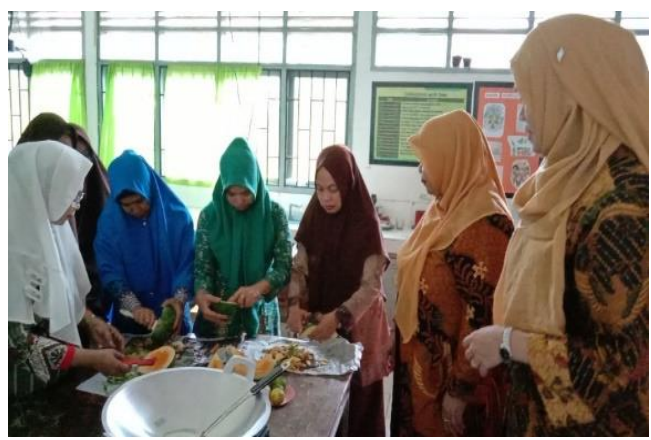

Gambar 2. Peserta pelatihan melakukan praktik membuat selai pepaya dan abon pepaya

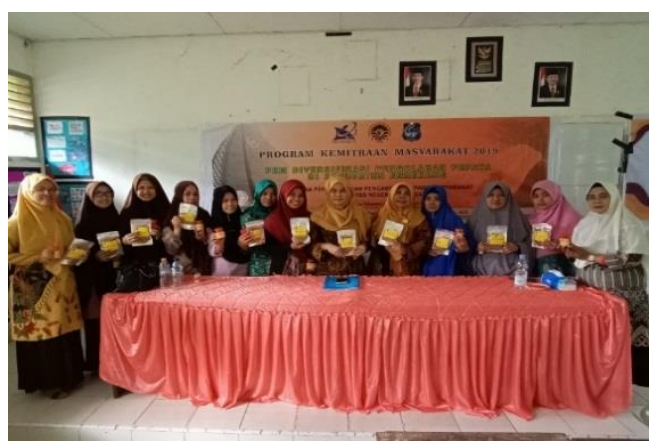

Gambar 3. Tim pelaksana bersama peserta menunjukkan hasil produk

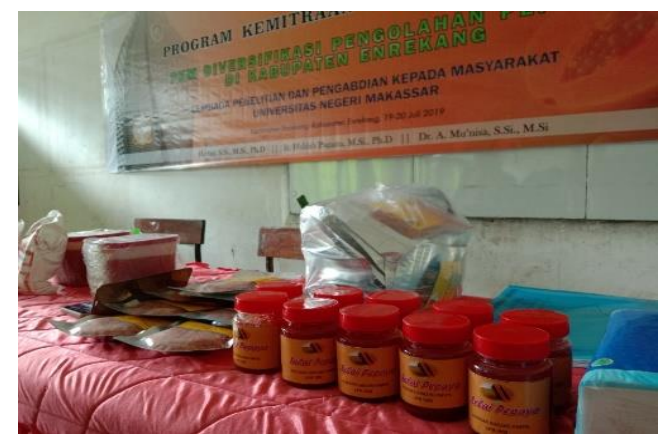

Gambar 4. Produk selai pepaya dan abon pepaya

\section{KESIMPULAN}

Kegiatan pengabdian kepada masyarakat dalam program kemitraan masyarakat (PKM) dapat dilaksanakan dan mendapat respon yang baik oleh masyarakat khususnya ibu-ibu rumah tangga di Kabupaten Enrekang. Kegiatan ini dapat meningkatkan pengetahuan dan keterampilan masyarakat di Kabupaten Enrekang dalam mengolah pepaya menjadi selai pepaya dan abon pepaya sehingga dapat meningkatkan nilai ekonomi. Produk ini dapat dikembangkan menjadi usahan rumahan bagi ibu-ibu di Kabupaten Enrekang. Peserta yang mengikuti kegiatan ini sangat aktif dalam melakukan praktik.

\section{DAFTAR PUSTAKA}

Peter K, Kumar JY, Pandey P, Mash H. 2014. Antibacterial Activity of see and leaf extract of Carica papaya var Pusa dwarf Linn. Journal of Pharmacy and Biological Sciences 9(2): 29-37.

Sulihandar and Hartanti. 2013. Herbal sayur dan buah ajaib trans idea, Publishing Yogyakarta.

Warisno, 2003. Budidaya pepaya, Yogyakarta. 